\title{
Creating space for quality improvement
}

\author{
(ㄷ) $(\mathbb{\theta} \Theta$ OPEN ACCESS \\ Clinicians already have the motivation; now they need time, skills, and support
}

\section{Dominique Allwood assistant director of improvement, Rebecca Fisher policy fellow, Will Warburton director of improvement, Jennifer Dixon chief executive}

Health Foundation, London, UK

Today The BMJ and the Health Foundation are launching a joint series of papers exploring how to improve the delivery of healthcare (https://www.bmj.com/quality-improvement). ${ }^{12}$ The series aims to discuss the evidence for systematic quality improvement, provide knowledge and support to clinicians, and ultimately to help improve care for patients.

Stories of a disordered system abound in healthcare: the notes or test results that don't arrive, the overbooked clinic, the frail patient who wastes hours travelling to and from an appointment that the hospital had rescheduled but failed to communicate. At the front line the problems frustrate, waste time, and add avoidable risk; at national level, they add up to slow progress on quality, wasted resource, and severely dented staff enthusiasm and public trust in the NHS.

Leaving aside the human cost of poorly managed care, the aggregate loss of value each year is high. In today's NHS, the pressure-from rising demand and a financial squeeze in the NHS and social care-is intense, with staff working flat out to do their best for patients, in many cases at great personal cost. Suggestions to those working at the front line that things could be done differently can be met with a chorus of: "But we have no time to think/no support/no power/no resources," sometimes followed by "the organisation or government must do something."

But some clinical teams do carve out the space to discover what needs to change, then design and make improvements to the services they are responsible for. ${ }^{3}$ There is no substitute-only clinicians, patients, and carers at the front line can see clearly every day what needs to change.

In making these improvements doctors have gone beyond their primary remit of practising medicine. If disordered care is to improve then we need more clinicians to view their role as bigger than the traditional scope of medicine taught at medical school. Just as doctors learn to assess, diagnose, and treat clinical conditions they also need to learn how to design improvements to services, including communicating and negotiating better within and beyond their teams on the best way forward. Like studying the science of medicine, to make improvements doctors need to apply scientific principles to the practice of everyday work and to test changes, analyse results, and adapt accordingly. This broad approach is loosely called quality improvement in healthcare.

The task ahead is not necessarily to turn doctors into managers, but the first step must be to equip doctors and other clinicians with formal skills to make continuous improvements to the quality of the services they provide. This means new technical and relational skills and behaviours.

Despite substantial debate, multiple initiatives to equip clinicians with quality improvement skills, and advances in defining the role of a doctor, ${ }^{4}$ medical training still does not help enough doctors to develop these skills. Audit (sometimes rebranded as quality improvement) is increasingly mandated as part of postgraduate clinical training but doctors are largely unsupported to do it, which risks quality improvement being viewed as a tick box exercise needed to get through annual appraisal.

While some royal colleges in the UK are making progress in introducing postgraduates to quality improvement, ${ }^{5-7}$ many places of work either do not recognise the need or offer no support. There is a widespread view, and implicit hope, that improvements to care occur at the front line by a kind of osmosis or, worse still, only through new technologies or "management," without careful ongoing systematic effort of clinical staff. A good time to excite doctors on this agenda should be early in their career. But junior doctors are on short rotations, have limited time to do anything, and may feel they are transient workers with no authority to improve existing practices.

No surprises then that juniors become cynical, senior clinicians don't know about or are sceptical about quality improvement approaches, and both may run a mile from a management perceived to be focused on financial control. Rather than try to 
improve a service, committed doctors may turn their energies elsewhere-to academic work, medical training, committee work, private practice-in fact, anywhere other than bettering everyday clinical work.

Yet there is plenty of evidence that systematic quality improvement makes a difference, not just for patients but for staff too. ${ }^{89}$ And despite everything many doctors in the wider NHS are motivated to reach beyond the boundaries of traditional medicine and improve care. The intrinsic motivation of healthcare professionals to improve care for patients could undoubtedly be put to more effective use with more knowledge, careful planned development of clinicians, and practical support. Our aim is that this series will contribute to these important goals.

Competing interests: We have read and understood BMJ policy on declaration of interests and have no relevant interests to declare.

Provenance and peer review: Commissioned; not externally peer reviewed.

This article is one of a series commissioned by The BMJ based on ideas generated by a joint editorial group with members from the Health Foundation and The BMJ, including a patient/carer. The BMJ retained full editorial control over external peer review, editing, and publication. Open access fees and The BMSs quality improvement editor post are funded by the Health Foundation.
1 De longh A, Erdmann S. Better healthcare must mean better for patients and carers. BMJ 2018;361:k1877.

2 Braithwaite J. Changing how we think about healthcare improvement. BMJ 2018;361:k2014.

3 Health Foundation. Improvement projects, tools and resources.http://www.health.org.uk/ collection/improvement-projects-tools-and-resources

4 GMC. Good medical practice. https://www.gmc-uk.org/-/media/documents/Good_medical_ practice English_1215.pdf 51527435.pdf

5 Royal College of General Practitioners. Quality improvement project. https://www.rcgp. org.uk/training-exams/mrcgp-workplace-based-assessment-wpba/qip-guidance.aspx

6 Peden C, ed. Quality improvement in anaesthesia. 2012. https://www.rcoa.ac.uk/system/ files/CSQ-ARB2012-QIA.pdf

7 Choudry MI, Stewart K, Woodhead T. The Royal College of Physician's quality improvement hub-how can it help physicians to improve patient care?Future Hospital Journal 2016;3:21106.

8 Pronovost P, Needham D, Berenholtz S, etal . An intervention to decrease catheter-related bloodstream infections in the ICU. N Engl J Med 2006;355:2725-32. 10.1056/NEJMoa061115 17192537

9 Salford Royal NHS Foundation Trust. Quality improvement strategy, 2015-2018. http:// www.srft.nhs.uk/EasysiteWeb/getresource. $a x d$ ? AssetID=39260\&type=full\& servicetype $=$ Inline

Published by the BMJ Publishing Group Limited. For permission to use (where not already granted under a licence) please go to http://group.bmj.com/group/rights-licensing/ permissionsThis is an Open Access article distributed in accordance with the Creative Commons Attribution Non Commercial (CC BY-NC 4.0) license, which permits others to distribute, remix, adapt, build upon this work non-commercially, and license their derivative works on different terms, provided the original work is properly cited and the use is non-commercial. See: http://creativecommons.org/licenses/by-nc/4.0/. 